\title{
Od socjalizmu do transformacji, czyli o chorwackiej kulturze i literaturze popularnej ostatnich pięciu dekad
}

\author{
Maša Kolanović, Udarnik! Buntovnik? Potrošač... \\ Popularna kultura i hrvatski roman od socijalizma do tranzicije, \\ Naklada Ljevak, Zagreb 2011, ss. 468
}

Imponujących rozmiarów książka Mašy Kolanović przygotowana została do druku na podstawie rozprawy doktorskiej Popularna kultura i hrvatski roman od socijalizma do tranzicije (Kultura popularna i powieść chorwacka od socjalizmu do transformacji), którą autorka obroniła na Wydziale Filologicznym Uniwersytetu w Zagrzebiu w kwietniu 2010 roku. Wprowadzona zmiana tytułu trafnie precyzuje dominujące w pracy pole problemowe. Równocześnie wydaje się świetnym zabiegiem marketingowym, gdyż już na wstępie sytuuje pozycję wśród aktualnych dyskursów kulturoznawczych i socjologicznych, przesuwając ją z ,wąskiego" kręgu literaturoznawstwa. Tytułowe określenia udarnik, buntovnik, potrošač (przodownik, buntownik, konsument) stanowią synekdochiczne reprezentacje typów tożsamości, które ukształtowały się w ramach jugosłowiańskiej i chorwackiej rzeczywistości społecznej, a także w literaturze i przestrzeni kultury popularnej w okresie od socjalizmu do transformacji.

Książka M. Kolanović składa się z trzech zasadniczych rozdziałów odznaczających się jednak sporą objętościową dysproporcją. W pierwszym z nich, Širenje granica književnoga teksta (Poszerzanie granic tekstu literackiego), autorka zajmuje się fenomenem chorwackiej powieści w kontekście szeroko rozumianej kultury popularnej od czasów jugosłowiańskiego socjalizmu do - wciąż trwającej - transformacji po ostatniej wojnie i rozpadzie Jugosławii. Interdyscyplinarne metodologiczne zakorzenienie pracy sytuującej się na przecięciu literaturoznawstwa, socjologii i badań 
nad kulturą Kolanović uzasadnia dostrzeżonym w trakcie analizy tekstów paralelizmem pomiędzy wcześniejszym (jugosłowiańskim) i współczesnym literackim obrazem chorwackiego społeczeństwa.

Przedmiotem zainteresowania drugiego, najobszerniejszego rozdziału Od socijalizma do tranzicije (Od socjalizmu do transformacji) jest zjawisko kultury popularnej (masowej) w konfrontacji z postawą intelektualisty (część pierwsza Intelektualna povijest/Historia intelektualna) oraz historia powieści (część druga Povijest romana/Historia powieści). Sięgając do czasów po II wojnie światowej, autorka zwraca uwagę na populistyczny charakter socrealizmu, kultury dla (pracujących) mas, obowiązującej do roku 1948 (rezolucji Biura Informacyjnego) i zamierającej na początku lat 50., kiedy, nie znajdując zbyt wielu naśladowców sowieckiego modelu, dogasał krótkotrwały blask realizmu socjalistycznego, ustępując miejsca nowym zjawiskom: jugosłowiańskiej cywilizacji boogie-woogie i prozachodniej polityce, które doprowadziły do otwarcia drzwi dla popkultury Made in USA. W opinii Kolanović konsekwencją zmian był binarny podział intelektualistów na rekrutujących się spośród kreegów akademickich i tych spoza instytucji (pisarze, publicyści, artyści i bohema).

Przechodząc do zagadnienia przemian z lat 50., 60., i 70., autorka eksponuje problematykę związaną z historią chorwackiej powieści, rozszerzeniem pojęcia pola literackiego (P. Bourdieu), a także ukształtowania się modelu proze u trapericama (jeans proza). Zwraca przy tym szczególną uwagę na monografię Aleksandra Flakera Proza u trapericama i głębokie zakorzenienie własnych badań $\mathrm{w}$ jego prekursorskiej i nieocenionej refleksji na temat tej odmiany powieści. Wzorzec jeans prozy przyniósł znaczącą falę zmian w kreowaniu świata literackiego, będącego przecież odzwierciedleniem przemian społecznych, uwarunkowanych w dużej mierze boomem kultury popularnej, konsumpcjonizmem mieszkańców ówczesnej Jugosławii, którego znakiem rozpoznawczym stały się dżinsy (traperice), coca-cola i guma do żucia oraz filmy amerykańskie, jazz i muzyka zespołu Rolling Stones. Kolanović przypomina fundamentalną konstatację Flakera, że podstawową zasadą konstrukcji jeans prozy była ideja osporavanja (idea negacji/zaprzeczania). Wniosek Flakera staje się matrycą dla dalszych analiz badaczki. W tekstach socrealizmu odnajduje ona „kody do zaprzeczenia" (kodovi za osporavanje): romans partyzancki, politykę płci w romansie, czarno-biały i zideologizowany obraz świata przedstawionego 
(partyzanci - Niemcy), a także partyzancki folklor, które zostaną następnie zanegowane przez jeans prozę. Nowy model powieści zastapi dotychczasowych bohaterów nowymi typami postaci: włóczędzy, bohema artystyczna oraz konsument. Wśród uruchomionych przez jeans prozę „kodów zaprzeczania" (kodovi osporavanja) - poza zamianą bohaterów - wyróżnia: historyczny typ negacji, politykę płci w powieści, zamianę wspólnoty narodowej przez grupę (klapę) czy kreację heterotopii. W przeciwieństwie do modelu socrealistycznego $\mathrm{w}$ jeans prozie zostają wyeksponowane: topos miasta jako scenografia głównych wydarzeń, topografia dokolice (czasu wolnego, rozrywki) i zmiany społeczne, wiodące w kierunku kultury konsumpcyjnej.

Poza oczywistymi różnicami Kolanović dostrzega podobieństwo poetyki socrealistycznej i literatury masowej, obie bowiem związane są z popkultura, posługująca się tymi samymi kodami konstrukcji dzieła, opartymi na stereotypowości. W przypadku „buntowniczej” jeans prozy zjawiska masowości autorka dopatruje się związku z popkulturą w celebrowaniu konsumpcyjnego stylu życia, czego jednym z przejawów jest również instrumentalne traktowanie kobiet przez głównego bohatera płci męskiej oraz ogólne umiejscowienie postaci kobiecych w dalszym planie powieściowym - zarówno $\mathrm{w}$ dziełach socrealizmu (męskocentryczne doświadczenie rzeczywistości wojennej, kult partyzantów), jak i jeans prozie, gdzie świat przedstawiony także został zdominowany przez mężczyzn, buntowników, członków nowych subkultur, dla których postaci kobiece stanowią jedynie „ciała” służące rozrywce.

W wielu miejscach badaczka przypomina, że projekt socrealizmu był w zamyśle populistyczny. Ludowa demokracja w Jugosławii traktowała naród jako kolektywnego odbiorcę masowej, popularnej twórczości socrealistycznej. Zgodnie z odgórnymi założeniami, tendencyjność literatury i jej propedeutyczny charakter, jak również walka z analfabetyzmem odgrywały kluczową rolę w projekcie upowszechnienia kultury. Na obszarze Jugosławii (i Chorwacji) już w latach 50. ukształtowało się społeczeństwo konsumpcyjne, które w następnej dekadzie rozwijało się dość dynamicznie, zostawiając ślad swoich symbolicznych pragnień przede wszystkim w kulturze popularnej i życiu codziennym. Zjawisko umasowienia kultury w XX wieku, szczególnie po II wojnie światowej, było silnie związane z produkcją przedmiotów codziennego użytku, czego konsekwencją stała 
się dominacja estetyki amerykańskiej i zachodniej popkultury, wraz z metaforą gumy do żucia, jako jednego z jej najważniejszych symboli. Amerykański wzorzec popkultury zadomowił się w Jugosławii już od początku lat 50. Sprzyjała temu sytuacja polityczna spowodowana rezolucją Biura Informacyjnego w roku 1948, tzw. otwarcie na Zachód, a także ogromny prestiż Międzynarodowych Targów w Zagrzebiu (Zagrebački Velesajam), będących wyznacznikiem mody i potrzeb ówczesnego konsumenta.

Powołując się na opinię Iana Chambersa, Maša Kolanović podkreśla, że zjawisko popkultury jest ściśle związane z pejzażem miejskim i w znacznym stopniu oddziałuje na transformację miejskiej codzienności. Tym samym miasto staje się najczęstszym toposem tekstów literackich, z silnym wyeksponowaniem domów towarowych, kawiarni, barów, coraz popularniejszych centrów handlowych; podczas gdy powieść socrealistyczna wyraźnie eksponuje wiejską czasoprzestrzeń. W konstrukcji bohatera literackiego miejsce przodownika i partyzanta zajmuje buntownik i włóczęga, później konsument.

W latach 70. XX wieku konsumpcjonizm stanowi integralną część jugosłowiańskiej socjalistycznej rzeczywistości, powodując, że na tle innych demoludów Jugosławia prezentuje się jako ,państwo dobrobytu”, co znajduje odzwierciedlanie $\mathrm{w}$ omawianych przez Kolanović powieściach (np. utwory Z. Majdaka, Kužiš, stari moj, Glista). Wiele miejsca autorka poświęca wspomnieniowo-autobiograficznej, reprezentatywnej pod tym względem prozie Gorana Tribusona, w której centralny motyw zajmuje właśnie kultura popularna z czasów jugosłowiańskiego socjalizmu, ujawniająca się w praktyce zaprzeczania i negacji ustroju i sytuacji politycznej. Dekadencki socjalizm (dekadentni socijalizam) zostaje wyparty przez coraz bardziej inwazyjny konsumpcjonizm kształtujący jugosłowiańskie społeczeństwo. Analizując specyfikę lat 80., badaczka podkreśla, że tamten czas charakteryzuje dominacja licznych subkultur, postawa buntu wobec rzeczywistości oraz pojawienie się grup punkowych i ich licznych naśladowców. U pisarzy takich jak Borivoj Radaković (Sjaj epohe) subkultura punk i nowa fala przemian społecznych stanowiły istotny kapitał symboliczny w formowaniu tożsamości głównego bohatera. Tym samym Kolanović wskazuje, że funkcja popkultury w strukturze powieści jest wielowymiarowa, pojawia się w formie komentarza do pewnych doświadczeń i nastrojów głównych postaci, nierzadko w opozycji do oficjalnego nurtu i ideologii państwowej. 
W wielu utworach z tego okresu na pierwszym planie znajduje się ponownie przestrzeń miejska, najczęściej Zagrzeb, miasto bowiem staje się pierwotnym miejscem artykulacji tożsamości.

Rozważania końcowe zawarte w rozdziale trzecim: Između teksta $i$ konteksta (Pomiędzy tekstem a kontekstem) stanowią trafną syntezę, ponieważ autorka zwraca uwagę na rzeczywistość chorwacką przełomu XX i XXI wieku, zmiany społeczno-kulturowe i powstające w tym okresie utwory literackie będące ich odzwierciedleniem. Szerokie spektrum przenalizowanej poetyki: od socrealizmu do šund-literatury i pojęcia trash daje istotny, panoramiczny ogląd problematyki kultury popularnej w kontekście przemian, które miały miejsce na terenie Chorwacji od czasów socjalizmu do obecnej transformacji (recepcja konsumpcjonizmu).

W badaniach dotyczących kultury popularnej i chorwackiej powieści Kolanović zręcznie łączy wiedzę literaturoznawczą, kroatystyczną z teorią studiów kulturowych i socjologicznych. Uradnik!, Buntovnik?, Potrošač... stanowi nowatorskie, interdyscyplinarne ujęcie tematu przemian społecznych i kulturowych w Jugosławii i Chorwacji, przejawiających się w realizacjach powieściowych kilku dekad. Przedmiotem rozważań autorki jest krótkotrwały socrealizm, dekadencki socjalizm (będący zapowiedzią transformacji), kontaminacja kultury konsumpcyjnej, a także zagadnienie tożsamości współczesnego bohatera (homo postcommunisticus). W swojej obszernej analizie Kolanović zajmuje się również zjawiskiem literatury „Śmieci” i gatunkiem trash, stosunkiem intelektualistów do kultury masowej w roli inicjatorki stereotypów. W ciekawej syntezie minionego półwiecza autorka proponuje świeże spojrzenie na sytuację społeczną i zmiany w obszarze literatury, nie powstrzymując się od zrywania woalek, związanych chociażby z dotychczasowym przemilczaniem recepcji socrealizmu w Jugosławii, przytaczając jego najbardziej sztandarowe dzieła (powieść J. Barkovicia czy poetykę socrealistyczną w twórczości V. Nazora). Porusza wiele ciekawych problemów, sytuując niektóre zjawiska literackie $\mathrm{w}$ kontekście popkultury, czego przykładem może być literatura trywialna, šund-literatura, i postulat jej głębokiej analizy, która działałaby propedeutycznie, prowadząc do afirmacji tzw. wysokiej literatury, poprzez ukazanie kontrastów między nimi. Również Festiwal Literatury Alternatywnej (Festival Alternativne Književnosti, w skrócie: FAK), zainicjowany w roku 2000, skupiający pisarzy z byłej Jugosławii, reprezentujących od- 
mienne poetyki, autorka postrzega przez pryzmat umasowienia i spopularyzowania kultury, w tym wypadku literatury, po pewnym zastoju spowodowanym wojna.

Kolanović konsekwentnie zrealizowała swoje założenia, ukazując przemiany w obszarze chorwackiej powieści i popkultury. Obszerny materiał badawczy został rzetelnie dobrany i chronologicznie uporządkowany. Książka stanowi istotny wkład nie tylko do kroatystycznych badań literaturoznawczych, ale także socjologicznych i kulturowych.

Ewa Szperlik 